\title{
Investigating of $\mathrm{N}$ and $\mathrm{K}$ Fertilizers on Yield and Components of Soybean (Glycine max (L.) Merr.)
}

\author{
Elahe Shahkoohmahally ${ }^{1} \&$ Shirin Shahkoohmahally ${ }^{2}$ \\ ${ }^{1}$ Department of Agronomy, Faculty of Agriculture, Islamic Azad of Gorgan, Gorgan, Iran \\ ${ }^{2}$ Department of Horticultural Science, Faculty of Agriculture, Shiraz University, Shiraz, Iran \\ Correspondence: Shirin Shahkoomahally, Faculty of Agriculture, Shiraz University, Shiraz, Iran. Tel: \\ 98-711-613-8154. E-mail: shirin.shahkoomahally@yahoo.com
}

Received: July 1, 2017

doi:10.5539/jas.v9n10p85
Accepted: July 30, $2017 \quad$ Online Published: September 15, 2017

URL: https://doi.org/10.5539/jas.v9n10p85

\begin{abstract}
Nitrogen and potassium fertilization have given variable results in increasing soybean yield. More information is needed about optimum potassium $(\mathrm{K})$ and nitrogen $(\mathrm{N})$ fertilizers placement for soybean. This study investigated the effect of different amounts of nitrogen and potassium on yield and its components on soybean cultivar DPX. Treatments include nitrogen (from urea) - Potash (potassium sulfate) in seven levels (N0-K0, N50-K0, N0-K20, N50-K20, N100-K50, N200-K100 and N250-K150 kg/ha) and factor inoculated and non-inoculated at two levels. Some growth parameters such as seed number, 100 seed weight, pod number, yield and harvest index were analyzed. There was significant difference between seed number and 100 seed weight. When the seeds were inoculated with bacteria, treatments N0-K0 and N250-K150 have a minimum and maximum number of seeds in these conditions, respectively. Also, the results showed that 100 seed weight in treatments inoculated with bacteria, N250-K150 most (24 g per plant) and N0-K0 minimal (14 g per plant), respectively. In the absence of inoculation with bacteria treated N0-K0 also had the lowest 100 seed weight. There was a positive correlation between number of pod per plant, yield and harvest index and $\mathrm{N}$ rate. Consequently the results demonstrated that increases in yields were necessarily related to increase in plant $\mathrm{N}$ and $\mathrm{K}$ content and inoculated with bacteria had a marginal effect.
\end{abstract}

Keywords: fertilizer, inoculated, soybean, nitrogen-potash

\section{Introduction}

Soybean (Glycine $\max$ (L.) Merr.) belongs to Papilionaceae family. Soybean is an herbaceous annual legume which was first cultivated in China as an oilseed. Today, about $50 \%$ of the world's oil is fed by soybean oil (Akparobi, 2009). Soybean categorizes as an ancient crop plant in the agriculture history (Jandong et al., 2011). It consists of essential neutrinos such as macro and micro nutrients, and uses for different aims for human needs, livestock (Akparobi, 2009; Berglund, 2009). Vahedi et al. (2010), and Eisa et al. (2011) introduced soybean as a suitable replacement to other oil and protein supplements. There has been slight increase in soybean production since 2000 across the world (Masuda \& Goldsmith, 2009).

Nitrogen is one of the essential elements in the production of dry matter and the regulation of photochemical processes in the plant (Sawan et al., 2006). Synthesis of fat requires both $\mathrm{N}$ and carbon skeletons during the course of seed development (Pattl et al., 1996). Nitrogen is also the main factor in protein production in the plant (Frink et al., 1999). On the other hand, excessive nitrogen increases plant growth and decreases the light intensity in canopy thereby reducing photosynthesis (Cothren, 1999). This attributed to the role of $\mathrm{K}$ in biochemical pathways in plants. Potassium affects photosynthesis processes by $\mathrm{CO}_{2}$ assimilation and facilitates carbon movement (Sangakkara et al., 2000). Also, potassium has important role on metabolism pathways of nucleic acids, proteins, vitamins and growth substances in plants (Bisson et al., 1994; Bednarz \& Oosterhuis, 1999). K affects the translocation of photosynthetic materials from sources to sinks (Cakmak et al., 1994). There has been several report of positive effect of K on the yield and quality (Mullins et al., 1991; Cassman et al., 1992). Nitrogen requirement for soybean is provided in a combination of soil-derived nitrogen and by the process of symbiotic fixation of Rhizobia bacteria. The supply of nitrogen depends on several factors such as the amount of nitrogen in the soil and the development of root nodes (Gan et al., 2003). 
There is no information available in the literature to evaluate soybean yield and its components responses to different amounts of nitrogen and potash fertilizers for optimizing these traits. Thereby, our studies were carried out to investigate the influence of $\mathrm{N}$ and $\mathrm{K}$ with inoculated with bacteria on yield of soybean.

\section{Materials and Methods}

This study was conducted in Gorgan, Iran during 2015 and 2016 growth seasons. Gorgan (latitude $45^{\circ} \mathrm{N}$, longitude $30^{\circ} \mathrm{E}$ ) is situated at $13 \mathrm{~m}$ above sea level. Daily rainfall and air temperature data were recorded at the experimental site or collected from the nearest weather station during (Table 1). Analysis of soil sample taken from 0-30 cm depth explained in Table 2. Soybean cultivar used in this experiment was DPX. The experiment was carried out in a randomized complete block with three replications. Each plot was $6 \mathrm{~cm}$ including six rows (4 m length and $6 \mathrm{~cm}$ row spacing). First factors were non-inoculated and inoculated with bacteria that seeds were pretreated with Rhizobium japonicum and control was done manually. Second factors were consisted nitrogen fertilizer (urea form) - Potash (potassium sulfate) in seven levels (N0-K0, N50-K0, N0-K20, N50-K20, $\mathrm{N} 100-\mathrm{K} 50, \mathrm{~N} 200-\mathrm{K} 100$ and $\mathrm{N} 250-\mathrm{K} 150 \mathrm{~kg} / \mathrm{ha}$ ). Ten plants selected to take the data from each plot of each replication. Data were recorded for number of seeds, 100 seed weight, number of pod per plant, yield and harvest index.

Table 1. Monthly mean temperatures and total rainfalls during the growing period of soybean

\begin{tabular}{lllllll}
\hline Month & $\begin{array}{l}\text { Maximum } \\
\text { Humidity }(\%)\end{array}$ & $\begin{array}{l}\text { Minimum } \\
\text { Humidity }(\%)\end{array}$ & $\begin{array}{l}\text { Precipitation } \\
(\mathrm{mm})\end{array}$ & $\begin{array}{l}\text { Maximum } \\
\text { temperature }\left({ }^{\circ} \mathrm{C}\right)\end{array}$ & $\begin{array}{l}\text { Minimum } \\
\text { temperature }\left({ }^{\circ} \mathrm{C}\right)\end{array}$ & $\begin{array}{l}\text { Evaporation } \\
(\mathrm{mm})\end{array}$ \\
\hline July & 76 & 49 & 51.2 & 33.5 & 24.2 & 218.5 \\
August & 76 & 48 & 43.3 & 35.1 & 25.4 & 245.5 \\
September & 83 & 55 & 49.3 & 29.7 & 20.8 & 153.4 \\
October & 87 & 53 & 133.7 & 26.6 & 15.5 & 123.5 \\
November & 94 & 68 & 67.6 & 15.3 & 8 & 47.2 \\
\hline
\end{tabular}

Table 2. Selected soil properties of the Ap horizon $(0-30 \mathrm{~cm})$ before soybean planting at Gorgan

\begin{tabular}{ll}
\hline Sample & Value \\
\hline Conductivity $(\mathrm{ds} / \mathrm{m})$ & 1 \\
$\mathrm{pH}$ & 7.6 \\
Organic materials $(\%)$ & 19.5 \\
$\mathrm{C}(\%)$ & 1.81 \\
$\mathrm{~N}(\%)$ & 0.18 \\
$\mathrm{P}(\mathrm{ppm})$ & 52 \\
\hline
\end{tabular}

Data were subjected to analysis of variance (GLM). Sources of variation were fertilizer at 7 levels and non-inoculated and inoculated with bacteria at 2 levels, and the interaction of both. Following normalization, data are smoothed to improve the validity of statistical inferences and to reduce inter-individual variation. Mean comparisons were performed using the Duncan's test to examine if differences between sources of variation were significant at $P \leq 0.05$. $P$ values were calculated according to Student's t test analysis. All analyses were performed with SAS software package v. 9.1 for Windows. Pearson correlation was used to prove the equivalence between yield and its components.

\section{Results}

\subsection{Seed Number}

Significant difference observed between the effects of fertilizers, inoculated with bacteria and their interactions on soybean seed number (Table 3). When the seeds were inoculated with bacteria, maximum and minimum number of seeds in T7 and T1 were obtained, respectively. Seed numbers in treatments T1 to T7, respectively, were as follows: 35, 41, 37, 43, 44, 53 and 56 (Figure 1). When the seeds were non-inoculated with bacteria, seed number between 144 and 246 numbers have changed. T1 and T7 have a minimum and maximum number of seeds in these conditions. The difference between the number of seeds inoculated with bacteria and non-inoculated with bacteria wasn't significant that it means bacteria doesn't effect on seed number but increased rate fertilizers, seed number increased significantly (Figure 1). 
Table 3. Analysis of variance of yield components

\begin{tabular}{lllllll}
\hline Source & df & Yield & Harvest index & 100 seed weight & Pod number & Seed number \\
\hline Block & 2 & $14209^{* *}$ & $17.6^{*}$ & $1.51^{*}$ & $11.8^{* *}$ & $12.5^{\mathrm{ns}}$ \\
Fertilizer (F) & 6 & $398540^{* *}$ & $64.1^{* *}$ & $36 / 94^{* *}$ & $76.8^{* *}$ & $2488.4^{* *}$ \\
Bacteria (B) & 1 & $1266203^{* *}$ & $325.5^{* *}$ & $4.34^{* *}$ & $24.8^{* *}$ & $22.5^{* *}$ \\
B $\times$ F $\times$ B & 6 & $61575^{* *}$ & $4.1^{\mathrm{ns}}$ & $6.5^{* *}$ & $3.6^{* *}$ & $23.5^{* *}$ \\
Error & 26 & $1827^{\mathrm{ns}}$ & $4.2^{\mathrm{ns}}$ & $0.29^{\mathrm{ns}}$ & $0.9^{\mathrm{ns}}$ & $0.8^{\mathrm{ns}}$ \\
\hline
\end{tabular}

Note. ${ }^{* *}, *$, ns: Significant at 1 and $5 \%$ probability levels and non-significant, respectively.

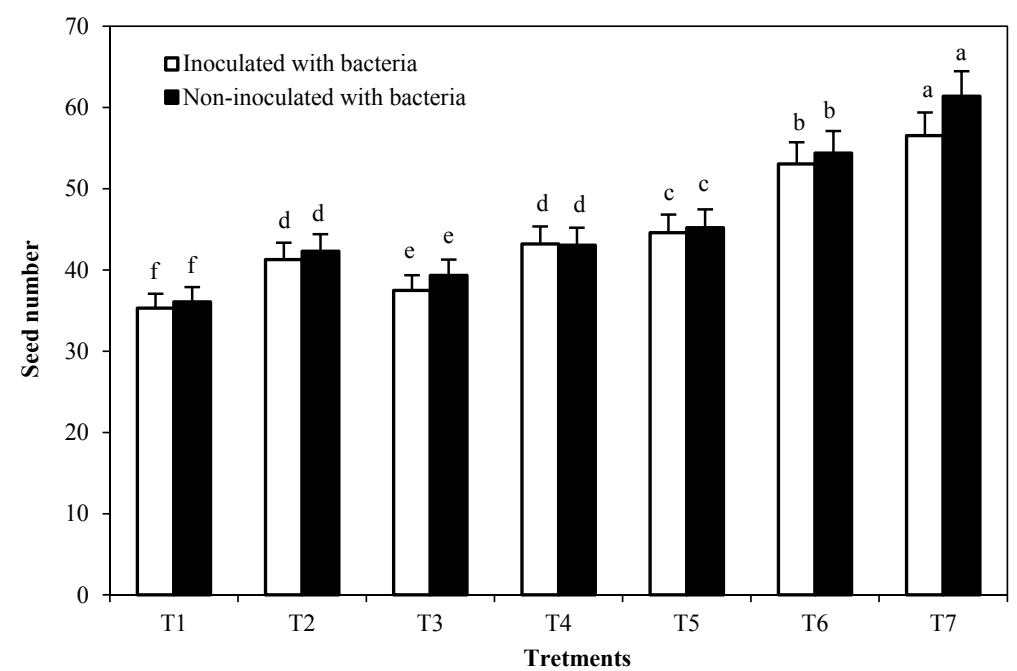

Figure 1. Effect of $\mathrm{N}$ and $\mathrm{k}$ on seed number on soybean. Means $\pm \mathrm{SE}$ with the same letter on top of bars within treatments do not differ significantly according to Student's t-test $(\mathrm{P}=0.05)$

\subsection{Seed Weight}

There were statistically difference between the fertilizers and soybean inoculated with bacteria and their interactions on seed number of soybean (Table 3). The results showed the difference between all the levels except T2 and T3 levels were significantly (Figure 2). In terms inoculated with bacteria, minimum and maximum were observed in T1 (14 g) and T7 (19.2 g), respectively. Inoculated with bacteria difference in fertilizers T1, T2 and $\mathrm{T} 3$ are not significant. In the absence of bacterial, treatments $\mathrm{T} 1$ also had the lowest seed weight and the difference was not significant between $\mathrm{T} 1$ and $\mathrm{T} 3$ but $\mathrm{T} 1$ and $\mathrm{T} 2$ had the difference significant (Figure 2). Result of interaction showed that between fertilizers inoculated with bacteria and non-inoculated with bacteria, seed weight at T1, T2, T3, T4 and T7 were statistically significant (Table 4). 


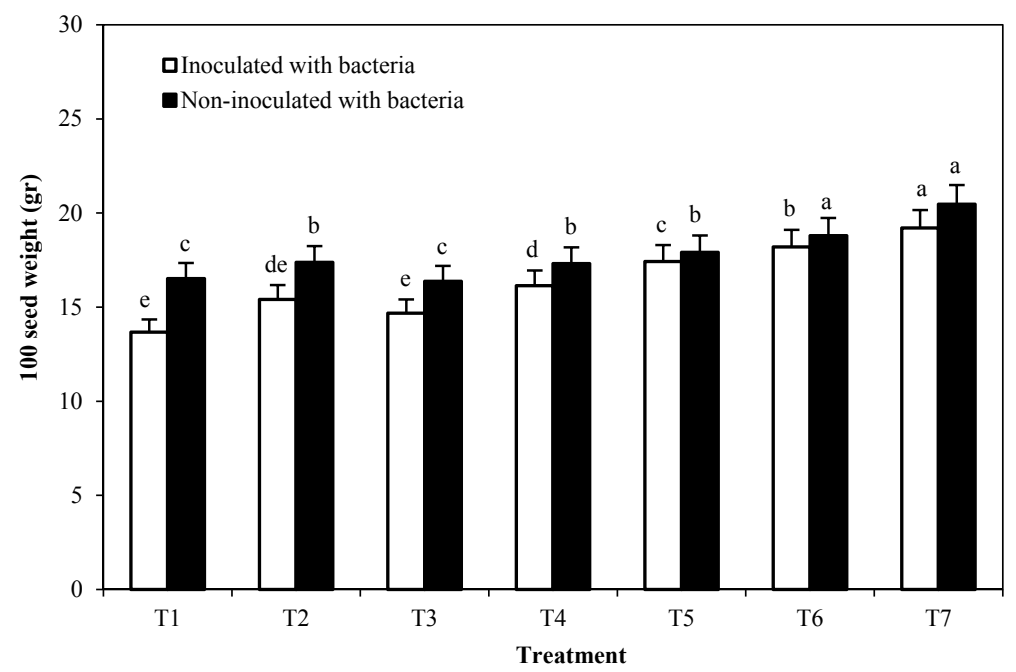

Figure 2. Effect of $\mathrm{N}$ and $\mathrm{k}$ on 100 seed weight on soybean. Means $\pm \mathrm{SE}$ with the same letter on top of bars within treatments do not differ significantly according to Student's t-test $(\mathrm{P}=0.05)$

Table 4. Interaction effect of fertilizers and yield and its components of soybean

\begin{tabular}{lllll}
\hline Treatments & Yield & 100 seed weight & Pod number & Seed number \\
\hline T1 & $22.81^{* *}$ & $42.41^{* *}$ & 0.59 & 1.03 \\
T2 & $38.10^{* *}$ & $20.26^{* *}$ & 0.05 & 1.79 \\
T3 & $7.94^{* *}$ & $14.97^{* *}$ & 0.10 & $5.90^{*}$ \\
T4 & $76.79^{* *}$ & $7.23^{*}$ & 1.30 & 0.04 \\
T5 & $185.89^{* *}$ & 1.24 & $6.66^{*}$ & 0.66 \\
T6 & $240.88^{* *}$ & 0.13 & $9.43^{* *}$ & 3.06 \\
T7 & $322.84^{* *}$ & $64.57^{* *}$ & $32.17^{* *}$ & $41.29^{* *}$ \\
\hline
\end{tabular}

\subsection{Yield}

The effects of treatments, inoculated with bacteria and the interaction of these two factors on soybean yield was significant (Table 3). The results showed that inoculation with bacteria at all levels of fertilizer on soybean yield increased (Figure 3). T7 fertilizer treatments in both levels of bacteria had highest yield and T1, T2 and T3 had the lowest yield (Figure 3). Interaction showed that the differences in all fertilizer with inoculated with bacteria were significantly, which means: all levels of fertilizer inoculated with bacteria improve soybean yield (Table 4). 


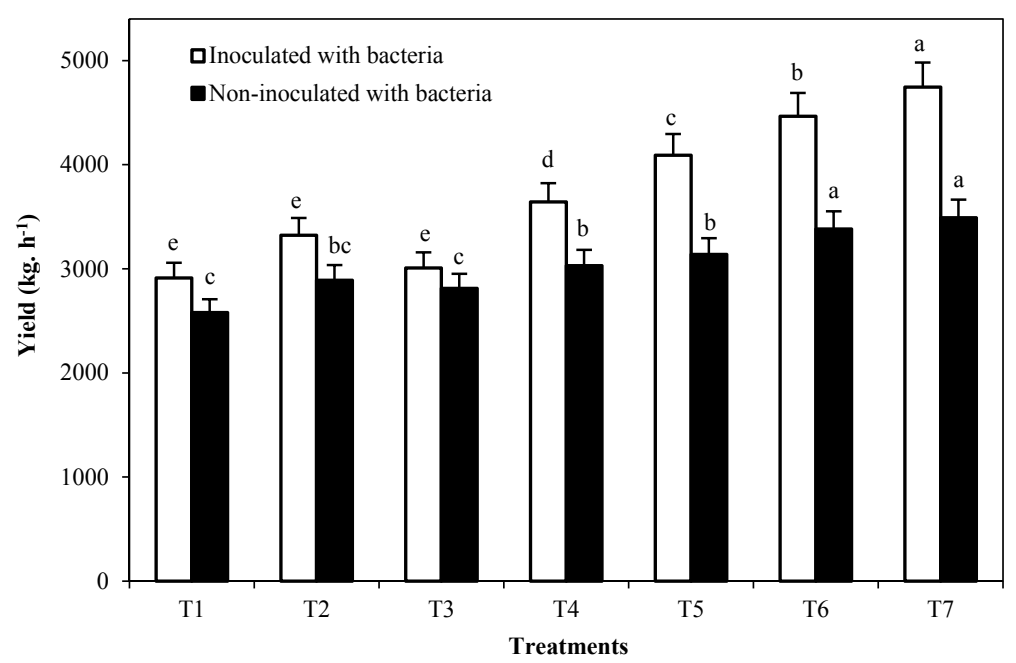

Figure 3. Effect of $\mathrm{N}$ and $\mathrm{k}$ on yeild on soybean. Means $\pm \mathrm{SE}$ with the same letter on top of bars within treatments do not differ significantly according to Student's t-test $(\mathrm{P}=0.05)$

\subsection{Harvest Index}

The results showed that the effect of fertilizer and inoculation with bacteria in soy harvest index was significant but the interaction was not significant (Table 3). T7 fertilizer treatments had highest harvest index was about $52 \%$ (Figure 4). This difference in treatment with other treatments was significant. Lowest harvest index were observed in $\mathrm{T} 1$ but there is no significant between T1 and T2 and T3 treatments. Harvest index of soybean inoculation with bacteria significantly increased (Figure 5). Harvest index inoculated with bacteria and noninoculated seed with bacteria was $48 \%$ and $43 \%$, respectively.

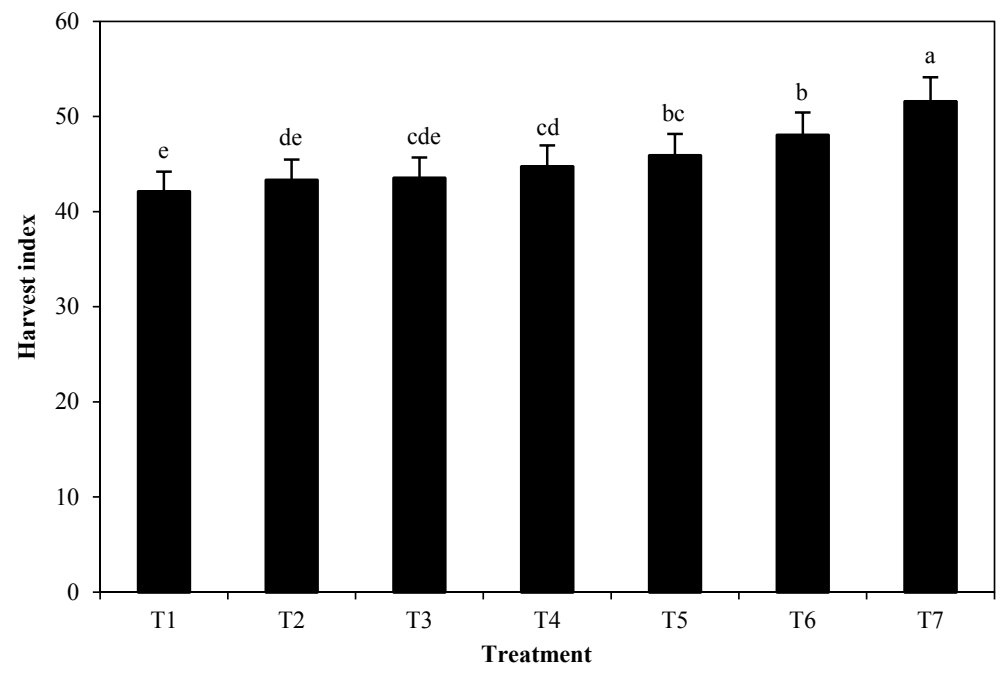

Figure 4. Effect of $\mathrm{N}$ and $\mathrm{k}$ on on harvest index on soybean. Means $\pm \mathrm{SE}$ with the same letter on top of bars within treatments do not differ significantly according to Student's t-test $(\mathrm{P}=0.05)$ 


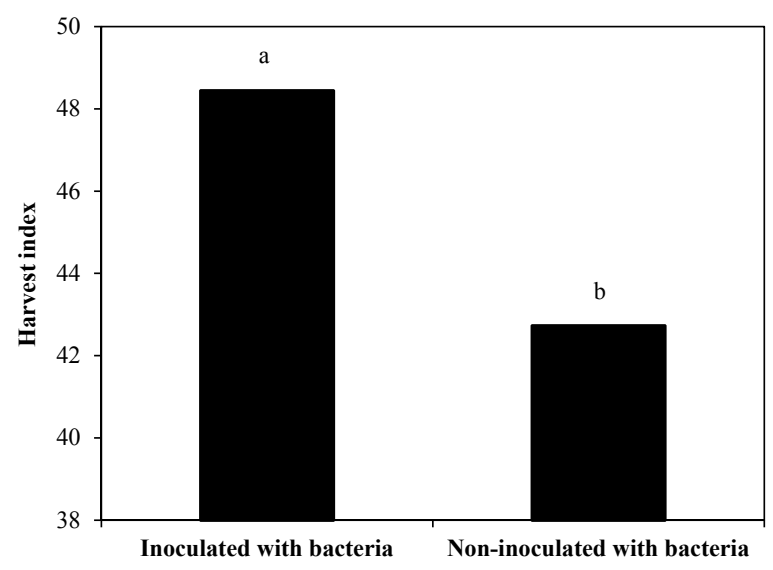

Figure 5. Effect of Inoculation on harvest index on soybean. Means $\pm \mathrm{SE}$ with the same letter on top of bars within treatments do not differ significantly according to Student's t-test $(\mathrm{P}=0.05)$

\subsection{Pod Number Plant}

The effects of treatments, inoculated with bacteria and their interactions on soybean pods were statistically significant (Table 3). In inoculation with bacteria, T7 had most (24) and T1 with 16 pods had the lowest pod number per plant (Figure 6). T7 and T6 were no significant differences. The difference between the levels of T4 and T5 with T6 were not significant. In non-inoculation with bacteria, All fertilizer levels had significantly different except T2 and T3 (Figure 6). T1 has minimal and T7 highest number of pods per plant. Interaction indicated that the difference between inoculated and non-inoculated bacteria on pods only at T5, T6 and T7 were significant (Table 4); this means that these 3 levels of fertilizer, inoculation with bacteria did not increase the number of pods.

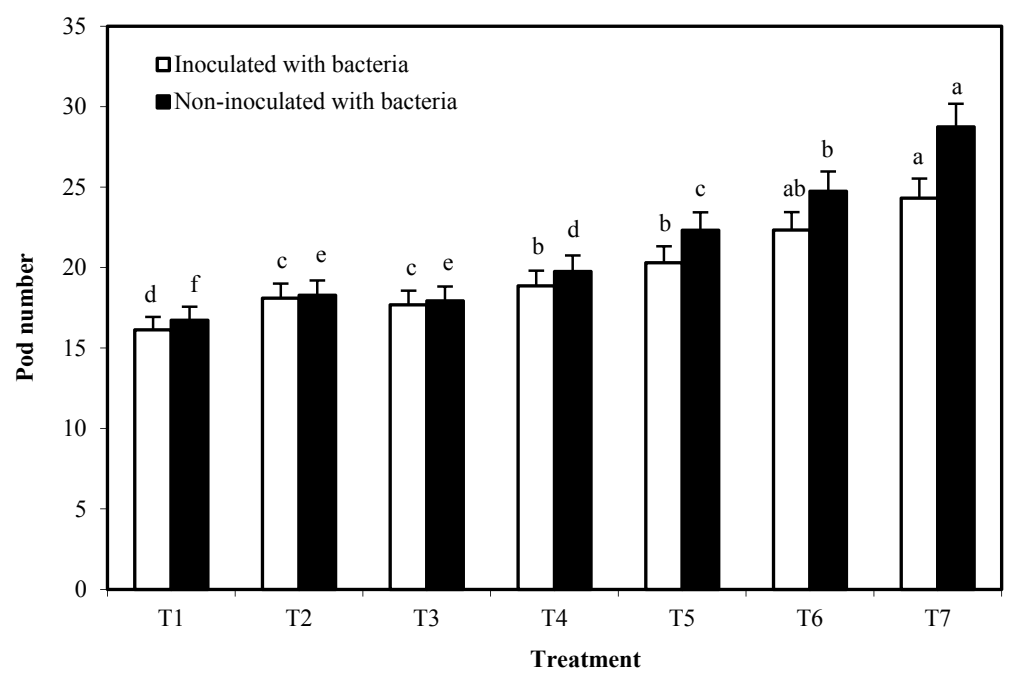

Figure 6. Effect of $\mathrm{N}$ and $\mathrm{k}$ on pod number on soybean. Means $\pm \mathrm{SE}$ with the same letter on top of bars within treatments do not differ significantly according to Student's t-test $(\mathrm{P}=0.05)$

\subsection{Correlation Coefficient of Yield and Its Components}

Table 5 presented the correlation between yield and other parameters. There was significant positive correlation among the number of seeds per plant, number of pods per plant and seed weight. Correlation coefficients indicated that soybean yield had positive and significant correlation with 100 grain weight $(r=0.69)$, number of pod per plant $(\mathrm{r}=0.53)$ and number of seed per pod $(\mathrm{r}=0.67)$. However, there was no significant correlation $(\mathrm{r}=$ 0.12 ) was found between yield and harvest index. 
Table 5. Correlation coefficient of yield and its components

\begin{tabular}{ll}
\hline & Yield \\
\hline Seed number & $0 / 67^{* *}$ \\
Pod number & $0 / 53^{* *}$ \\
100 seed weight & $0 / 69^{* *}$ \\
Harvest index & $0 / 12^{\mathrm{ns}}$ \\
\hline
\end{tabular}

Note. ${ }^{* *},{ }^{*}$, ns: Significant at 1 and $5 \%$ probability levels and non-significant, respectively.

\section{Discussion}

100 seed weight of soybean was influenced by the amounts of nitrogen uptake. In general, all of the nitrogen doses produced 100 seed weight higher than the non-nitrogen application condition. These results are in agreement with other (Taylor et al., 2005). Also, Channabasavanna and Setty (Channabasavanna \& Setty, 1994) reported positive response of seed weight to $\mathrm{N}$ application. There is report that 100 seed weight is not affected by nitrogen application (Barker \& Sawyer, 2005).

Number of seed increased with increasing $\mathrm{N}$ and $\mathrm{K}$ rates (Figure 1). These findings are in line with the reports of other work (Bahmanyar \& Mashaee, 2012). It seems that the cause of increase in grain number at high $\mathrm{N}$ level caused severe competition for carbohydrates, which resulted in increased hollow grain percentage. In lower nitrogen levels, insufficient nutrients for filling of grains led to diminished grain number per panicle; thus in this state, lower competition is the cause of decreased hallow grain percentage in panicle (Bahmanyar \& Mashaee, 2012).

All levels of fertilizer inoculated with bacteria improve soybean yield (Figure 3). Most concentration of $\mathrm{N}$ and $\mathrm{K}$ (T7) in both levels of bacteria had highest yield (Figure 3). According to the results of this study, soybeans inoculation with bacteria and greater use of nitrogen fertilizers were improved yield in soybeans than control. Much evidence suggests that the appropriate response of soybean to soil fertility and fertilization (Marschner \& Rimmington, 1996; Wesley et al., 1998). However, some research suggests that the soybean nitrogen fixation cannot provide sufficient nitrogen (Weber, 1966; Wesley et al., 1998). Also Syverud et al. (1980) reported to reduce the concentration of nitrogen in soybean crops during the dry season, they concluded that nitrogen supplementation is vital to maximize the yield. Taylor et al. (2005) also concluded that nitrogen fertilizer resulted in higher yield in soybean. This observation has been reported by other author (Kumar et al., 2013). Mishra and Singh (2006) observed that treatment in increasing levels also improved the yield and yield attributor characters. Kumar and Rao (1992), and Channabasavanna and Setty (1994) also reported findings indicating improvements in grain yields attributed to increments in yield components, which have to do with better nutrition, plant growth and increased nutrient uptake (Kumar \& Rao, 1992).

Net photosynthetic rate and dramatic decrease in crop yield were affected by K deficiency (Ding et al., 2006). De Datta and Gumez (1982) reported that K is vital factor for filling grain due to its deficiency ends up sterility of pollen seeds at the reproductive stage and result in decreased number of filled grains. This result was supported by Wang et al. (2004), and Kanda and Dixit (1996). De Datta et al. (1988) showed that the effect of nitrogen on yield significantly affected the response to potassium presence; when nitrogen fertilizers are not utilized, rice do not react to potassium fertilizer.

Nitrogen fertilization increased number of pods. Increase in number of pods could be as a result of nitrogen being involved in carbohydrate and protein metabolism that affect physiological process such as cell division and enlargement, in other words, more productive pods and dry matter yields. Other finding has been reported that increasing N rate results in increasing pods numbers (Malik et al., 2003; Shehu et al., 2010).

Consequently, the correlation between performance and other measured parameters showed that the number of seeds per plant, number of nodes per plant, number of pods per plant, seed weight, leaf dry weight, stem weight had significant positive correlation (Table 5). Yield and harvest index showed no significant correlation could be due to increased economic and biological function of both the same size (Table 5). Our findings were in line with the other observations by Showkat and Tyagi (2010) and Arshad et al. (2006) who reported that positive and significant correlation were among yield, number of pods per plant and 100 seed weight. Kumudini et al. (2001) also concluded that there is a significant and positive correlation between yield and component of soyebean. Shiraiwa et al. (2004) reported pod seed number as determinant factors of soybean yield. 


\section{Conclusion}

Finally, soy cultivation requires much nitrogen as a protein plant. The proper use of nitrogen fertilizer and seed inoculation with bacteria lead to improvement of soybean yield. Generally, availability of nitrogen results in more vegetative growth, thereby, the number of pods per plant and seed weight per plant contributes to higher soybean yield.

\section{References}

Akparobi, S. (2009). Evaluation of six cultivars of soybean under the soil of rainforest agro-ecological zones of Nigeria. Middle-East Journal of Scientific Research, 4(1), 06-09.

Arshad, M., Ali, N., \& Ghafoor, A. (2006). Character correlation and path coefficient in soybean Glycine max (L.) Merrill. Pakistan Journal of Botany, 38(1), 121.

Bahmanyar, M., \& Mashaee, S. S. (2012). Influences of nitrogen and potassium top dressing on yield and yield components as well as their accumulation in rice (Oryza sativa). African Journal of Biotechnology, 9(18), 2648-2653.

Barker, D. W., \& Sawyer, J. E. (2005). Nitrogen application to soybean at early reproductive development. Agronomy Journal, 97(2), 615-619. https://doi.org/ 10.2134/agronj2005.0615

Bednarz, C., \& Oosterhuis, D. (1999). Physiological changes associated with potassium deficiency in cotton. Journal of Plant Nutrition, 22(2), 303-313. https://doi.org/10.1080/01904169909365628

Berglund, D. R. (2009). Soybean production field guide for north Dakota and northwestern Minnesota.

Bisson, P., Cretenet, M., \& Jallas, E. (1994). Nitrogen, phosphorus and potassium availability in the soil-physiology of the assimilation and use of these nutrients by the plant. Challenging the Future: Proceedings of the World Cotton Research Conference (pp. 14-17).

Cakmak, I., Hengeler, C., \& Marschner, H. (1994). Partitioning of shoot and root dry matter and carbohydrates in bean plants suffering from phosphorus, potassium and magnesium deficiency. Journal of Experimental Botany, 45(9), 1245-1250. https://doi.org/10.1093/jxb/45.9.1245

Cassman, K., Bryant, D., \& Roberts, B. (1992). Cotton response to residual fertilizer potassium on vermiculitic soil: Organic matter and sodium effects. Soil Science Society of America Journal, 56(3), 823-830. https://doi.org/10.2136/sssaj1992.03615995005600030025x

Channabasavanna, A., \& Setty, R. (1994). Response of broadcast rice (Oryza sativa) to levels of nitrogen, phosphorus and potassium and time of $\mathrm{N}$ application. Indian Journal of Agronomy, 39(3), 457-458.

Cothren, J. (1999). Physiology of the cotton plant. Cotton: Origin, History, Technology, and Production (pp. 207-268). John Wiley \& Sons, Inc., Danvers, MA.

De Datta, S. K., Gomez, K. A., \& Descalsota, J. (1988). Changes in yield response to major nutrients and in soil fertility under intensive rice cropping. Soil Science, 146(5), 350-358. https://doi.org/10.1097/00010694198811000-00007

De Datta, S., \& Gomez, K. (1982). Changes in phosphorus and potassium responses in wetland rice soils in South and South-East Asia. Phosphorus and Potassium in the Tropics (pp. 127-146). The Malaysian Society of Soil Science, Kuala Lumpur, Malaysia.

Ding, Y., Luo, W., \& Xu, G. (2006). Characterisation of magnesium nutrition and interaction of magnesium and potassium in rice. Annals of Applied Biology, 149(2), 111-123. https://doi.org/10.1111/j.1744-7348.2006. 00080.x

Eisa, A., Taha, M. B., \& Abdalla, A. (2011). Amendment of soil fertility and augmentation of the quantity and quality of soybean crop by using phosphorus and micronutrienrs. International Journal of Academic Research, 3(2).

Frink, C. R., Waggoner, P. E., \& Ausubel, J. H. (1999). Nitrogen fertilizer: Retrospect and prospect. Proceedings of the National Academy of Sciences, 96(4), 1175-1180. https://doi.org/10.1073/pnas.96.4.1175

Gan, Y., Stulen, I., van Keulen, H., \& Kuiper, P. J. (2003). Effect of N fertilizer top-dressing at various reproductive stages on growth, $\mathrm{N}_{2}$ fixation and yield of three soybean (Glycine max (L.) Merr.) genotypes. Field Crops Research, 80(2), 147-155. https://doi.org/10.1016/S0378-4290(02)00171-5

Jandong, E., Uguru, M., \& Oyiga, B. (2011). Determination of yield stability of seven soybean (Glycine max) genotypes across diverse soil pH levels using GGE biplot analysis. J. Appl. Biosci., 43, 2924-2941. 
Khanda, C., \& Dixit, L. (1996). Effect of zinc and nitrogen fertilization on yield and nutrient uptake of summer rice (Oryza sativa). Indian Journal of Agronomy, 41(3), 368-372.

Kumar, K., \& Rao, K. (1992). N and P requirement of upland rice in Manipur. Oryza, 29, 306-306.

Kumar, M., Meena, M., Kumar, S., Maji, S., \& Kumar, D. (2013). Effect of nitrogen, phosphorus and potassium fertilizers on the growth, yield and quality of tomato var. Azad T-6. Asian Journal of Horticulture, 8(2), 616-619.

Kumudini, S., Hume, D. J., \& Chu, G. (2001). Genetic Improvement in Short Season Soybeans. Crop Science, 41(2), 391-398. https://doi.org/10.2135/cropsci2001.412391x

Malik, M. A., Saleem, M. F., Cheema, M. A., \& Ahmed, S. (2003). Influence of different nitrogen levels on productivity of sesame (Sesamum indicum L.) under varying planting patterns. Int. J. Agric. Biol., 5(4), 490-492.

Marschner, H., \& Rimmington, G. (1996). Mineral nutrition of higher plants. Wiley Online Library.

Masuda, T., \& Goldsmith, P. D. (2009). World soybean production: Area harvested, yield, and long-term projections. International Food and Agribusiness Management Review, 12(4), 143-162.

Mishra, D., \& Singh, L. (2006). Effect of N, P fertilization on the performance and production economics of rainfed okra intercropped with tomato under mid-hill condition of Uttranchal. Environment and Ecology, 24(3), 546.

Mullins, G., Burmester, C., \& Reeves, D. (1991). Cotton response to the deep placement of potassium on Alabama soils. Proceedings-Beltwide Cotton Conferences (USA).

Pattl, B., Lakkineni, K., \& Bhargava, S. (1996). Seed Yield and Yield Contributing Characters as Influenced by N Supply in Rapeseed - mustard. Journal of Agronomy and Crop Science, 177(3), 197-205. https://doi.org/ 10.1111/j.1439-037X.1996.tb00237.x

Sangakkara, U., Frehner, M., \& Nösberger, J. (2000). Effect of soil moisture and potassium fertilizer on shoot water potential, photosynthesis and partitioning of carbon in mungbean and cowpea. Journal of Agronomy and Crop Science, 185(3), 201-207. https://doi.org/10.1046/j.1439-037x.2000.00422.x

Sawan, Z. M., Hafez, S. A., Basyony, A. E., \& Alkassas, A. (2006). Cottonseed, protein, oil yields and oil properties as affected by nitrogen fertilization and foliar application of potassium and a plant growth retardant. World J. Agric. Sci., 2(1), 56-65.

Shehu, H., Kwari, J., \& Sandabe, M. (2010). Effects of N, P and K fertilizers on yield, content and uptake of N, P and $\mathrm{K}$ by sesame (Sesamum indicum). International Journal of Agriculture and Biology, 12(6), 845-850.

Shiraiwa, T., Ueno, N., Shimada, S., \& Horie, T. (2004). Correlation between yielding ability and dry matter productivity during initial seed filling stage in various soybean genotypes. Plant Production Science, 7(2), 138-142. https://doi.org/10.1626/pps.7.138

Showkat, M., \& Tyagi, S. (2010). Correlation and path coefficient analysis of some quantitative traits in soybean (Glycine max L. Merrill). Res. J. Agric. Sci., 1(2), 102-106.

Syverud, T., Walsh, L., Oplinger, E., \& Kelling, K. (1980). Foliar fertilization of soybeans (Glycine max L.). Communications in Soil Science \& Plant Analysis, 11(6), 637-651. https://doi.org/10.1080/0010362800 9367069

Taylor, R. S., Weaver, D. B., Wood, C., \& van Santen, E. (2005). Nitrogen application increases yield and early dry matter accumulation in late-planted soybean. Crop Science, 45(3), 854-858. https://doi.org/10.2135/ cropsci2003.0344

Vahedi, A. (2010). Study of the effects of micronutrient application on the absorption of macro-and micronutrients in the soybean cultivar Telar in the north of Iran. J. Am. Sci., 7(6).

Wang, Q., Zhen, R., Ding, Y., Ji, Z., Cao, W., \& Huang, P. (2004). Effects of potassium fertilizer application rates on plant potassium accumulation and grain quality of japonica rice. Scientia Agricultura Sinica, 10, 007.

Weber, C. (1966). Nodulating and nonnodulating soybean isolines: II. Response to applied nitrogen and modified soil conditions. Agronomy Journal, 58(1), 46-49. https://doi.org/10.2134/agronj1966.00021962005800 $010015 x$ 
Wesley, T., Lamond, R., Martin, V., \& Duncan, S. (1998). Effects of late-season nitrogen fertilizer on irrigated soybean yield and composition. Journal of Production Agriculture, 11(3), 331-336. https://doi.org/10.2134/ jpa1998.0331

\section{Copyrights}

Copyright for this article is retained by the author(s), with first publication rights granted to the journal.

This is an open-access article distributed under the terms and conditions of the Creative Commons Attribution license (http://creativecommons.org/licenses/by/4.0/). 